\title{
Modelling of various railway brakes types in the individual vehicles for the simulation of train motion
}

\begin{abstract}
The article presents the expanding of the prepared by author method of the modelling of the whole train pneumatic braking system. The model consists of various parts connected with continuous model of the braking pipe. The expanding of the model allow use of the various braking component in individual cars. In the paper are presented variants of the method, examples of the results and the practical advantages of this expanding.
\end{abstract}

\section{Modelowanie różnych rodzajów hamulców kolejowych w poszczególnych pojazdach dla symulacji ruchu pociągu}

\begin{abstract}
Artykut prezentuje rozszerzenie opracowanej przez autora metody modelowania uktadu hamulca pneumatycznego całego pociagu. Model składa się z różnych części składowych spojonych modelem ciagłym układu przewodu głównego. Rozszerzenie polega na możliwości występowania $w$ symulowanym pociagu różnych komponentów hamulcowych na poszczególnych wagonach. Przedstawiono warianty metody, przyktady wyników i praktyczne znaczenie tych rozszerzeń.
\end{abstract}

\section{Wprowadzenie}

Wprowadzanie w Europie pociagów towarowych o znacznej masie całkowitej i długości oraz pociągów pasażerskich o coraz większych prędkościach maksymalnych wymaga stosowania $\mathrm{w}$ pracach projektowych także zaawansowanych metod symulacyjnych hamulca. Podstawowym hamulcem pociagów jest hamulec pneumatyczny i taki rozpatruje się w niniejszym artykule.

Autor artykułu utworzył szeroko rozumiane metody modelowania układów hamulców pneumatycznych pociagów:

- modelowanie poszczególnych aparatów hamulcowych np. pojedynczych zaworów i układu hamulcowego pojedynczego pojazdu

- modelowanie układu hamulcowego całego pociagu

- modelowanie dynamiki wzdłużnej hamowanego pociagu.

$\mathrm{Na}$ modelach tych dokonano różnorodnych obliczeń układu hamowania pociągu dotyczących zarówno problemów naukowych, jak i utylitarnych.

Ostatecznym celem analiz hamowania calego pociągu są:

- prędkość fali hamowania

- $\quad$ przebieg spadku ciśnienia w przewodzie głównym wzdłuż pociagu

- czas napełniania cylindrów hamulcowych wzdłuż pociagu

- droga hamowania pociagu

- $\quad$ siły międzywagonowe występujące w procesie hamowania.

\section{Introduction}

Introduction in Europe the freight trains with the large total weight and length of trains and the passenger trains with the increasing maximum speeds requires using also the advanced simulation methods of the brake in the design works. The basic brake in trains is a pneumatic brake and this is considered in this article.

The author of this article created the widely understood methods of modelling of the pneumatic brake systems of trains:

- modelling of the individual brake devices e.g. single valves and the brake systems of the single vehicle

- modelling of the brake system of the whole train

- modelling of the longitudinal dynamics of braked train.

On these models the various calculations of the braking of the train concerning both the scientific and utilitarian problems were made.

The final goals of the analyses of the whole train braking are:

- $\quad$ speed of braking wave

- course of the pressure drop in the main pipe along the train

- time of filling of the brake cylinders along the train

- $\quad$ braking distance of the train

- interwagon forces occurring in the braking process. 
Odrębnym zagadnieniem jest odhamowanie pociagu, a w szczególności:

- czas i przebieg odhamowania składu

- badanie ewentualności przepełnienia hamulca.

Publikacje dotyczące metod symulacyjnych układy pneumatycznego hamulca i hamowania pociagów pojawiają się $\mathrm{w}$ różnych częściach świata, na przykład $[1,2,3,4,6,10,11]$. Metoda przedstawiona przez autora $[5,6,8]$ posiada dużą dokładność modelowania i symulacji części pneumatycznej hamulca, jej weryfikację doświadczalną przedstawiono m.in. w [7].

Jedną z części modelowania układu całopociagowego hamulca jest modelowanie zaworów rozrządczych i par ciernych hamulca. Do ogólnych analiz hamowności pociagu jest możliwe wykorzystanie uniwersalnego modelu zaworu rozrządczego lub jednego z bardziej szczegółowych modeli konkretnych zaworów.

Celem działań przedstawionych $w$ tym artykule jest rozszerzenie modelu o możliwość zestawienia (modelowego) składu pociągu wyposażonego w różne układy hamulcowe oraz różne rodzaje elementów ciernych hamulca na poszczególnych pojazdach. Łączenie w pociąg wagonów posiadających różne układy hamulcowe odpowiada normalnej praktyce kolejowej.

Przedstawiono przykładowe wyniki całopociagowych symulacji hamulca.

\section{Układ hamulcowy}

W skład układu hamulcowego pociagu wchodzą elementy zamontowane na lokomotywie:

- sprężarka

- zbiornik główny

- zawór maszynisty

oraz zespoły, które mogą być umieszczane na każdym pojeździe:

-zawory rozrządcze wraz z przyspieszaczami hamowania

- zbiorniki wagonowe

- siłowe elementy wykonawcze, przeważnie

cylindry hamulcowe

- pary cierne.

Pojazdy pociagu połączone są przewodem głównym, łączącym cały pneumatyczny układ hamulcowy. Schemat części pneumatycznej układu hamulcowego pociagu przedstawiono na rys. 1 .
Another issue is releasing of the train, and in particular:

- time and course of releasing of the train

- study of the possibility of brake overfilling.

Publications concerning the simulation methods of pneumatic braking systems and train braking appear in the different parts of the world, for example $[1,2,3,4$, $6,10,11]$. The method presented by the author $[5,6$, $8]$ has the high accuracy of modelling and simulation of the pneumatic part of the brake, its experimental verification is shown, among others, in [7].

One part of the modelling of brake system in the whole train is modelling of the control valves and a friction pairs of brake. For the general analyses of train braking it is possible to use an universal model of a control valve or one of the more detailed models of the specific valves.

The aim of the activities presented in this article is the extension of the model by the possibility of making (modelling) of train set equipped with the different braking systems and the different types of brake friction elements on the individual vehicles. Connecting the wagons in the train with the different brake systems corresponds to the normal railway practice.

The examples of the results of the brake simulation of the whole train are presented.

\section{Braking system}

The train braking system contains the elements mounted on the locomotive:

- compressor

- main tank

- driver's valve

and the units that can be placed on each vehicle:

-control valves with the braking accelerators

- wagon tanks

- force actuators, mostly brake cylinders

- friction pairs.

Vehicles of the train are connected by the main pipe, connecting the whole pneumatic braking system.

Diagram of the pneumatic part of train braking system is shown in Fig. 1.
Rys. 1. Schemat ogólny części pneumatycznej układu hamulcowego pociagu

Fig. 1. General diagram of the pneumatic part of train braking system.

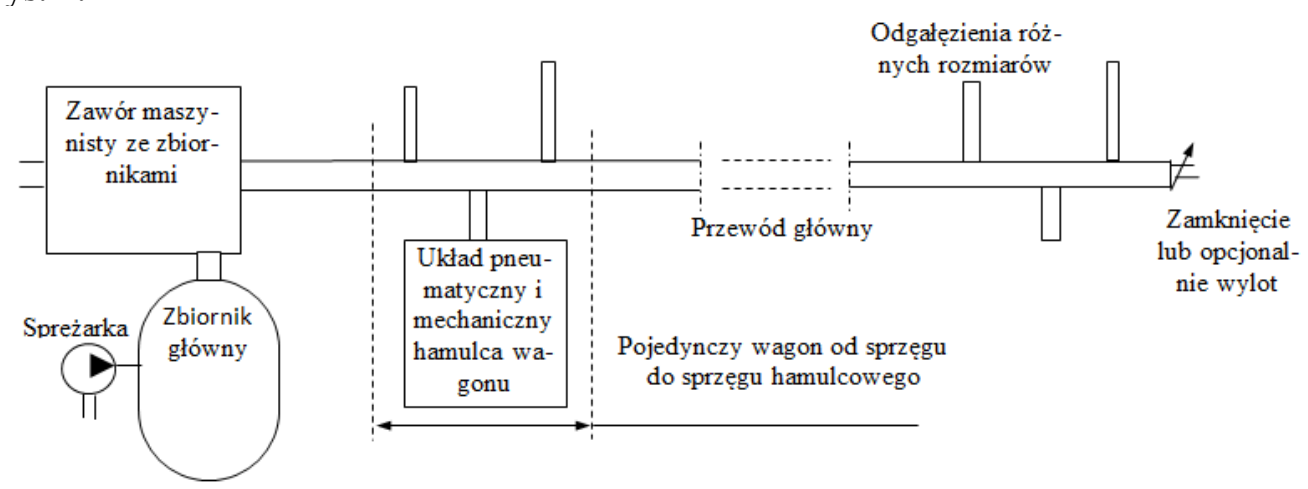




\section{Układ hamulcowy wagonu, przewód główny}

Część pneumatyczną układu hamulcowego wagonu przedstawiono na rys 2 .

Stalowy przewód główny jest elementem układu hamulcowego każdego wagonu, łączącym wagony $\mathrm{w}$ całym pociągu. Posiada on na każdym wagonie przeważnie formę przedstawioną na rys. 2. Istnieje w nim zawsze jeden kanał przepływu powietrza wzdłuż pociągu (o odcinkowo różnych przelotach i formie), a poszczególne wagony łączone są sprzęgami elastycznymi (gumowymi), może on posiadać przyłączenia różnych aparatów hamulcowych i zakończone ślepo odgałęzienia.

\section{Braking system of wagon, main pipe}

The pneumatic part of the wagon braking system is shown in Figure 2.

The steel main pipe is the component of the braking system of each wagon, connecting wagons in the whole train. On each wagon it usually has the form presented in Fig. 2. Always in it there is one channel of air flow along the train (with different passages and form on the sections), and the individual wagons are connected with the flexible couplings (rubber), it may have the connections of the various braking devices and the blindly ended branches.

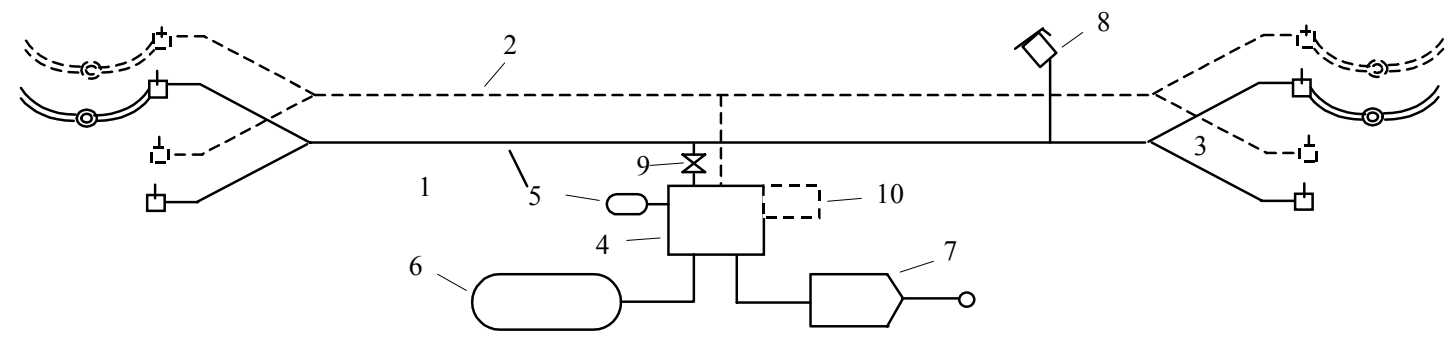

Rys. 2. Główne elementy układu pneumatycznego na wagonie

1 - przewód główny, 2 - przewód zasilający, 3 - odgałęzienia, 4 - zawór rozrządczy, 5 - zbiornik przyspieszacza (wewnątrz zaworu rozrządczego), 6 - zbiornik pomocniczy, 7 - cylinder hamulcowy, 8 - zawór bezpieczeństwa, zawór, 9 wyłącznik hamulca, 10 - zawór elektropneumatyczny.

Fig. 2. Main elements of the pneumatic system on the wagon

1 - brake pipe, 2 - main pipe, 3 - branches, 4 - control valve, 5 - accelerator's tank (inside of control valve), 6 - auxiliary tank, 7 - brake cylinder, 8 - safety valve, 9 - brake switch, 10 - electro-pneumatic valve.

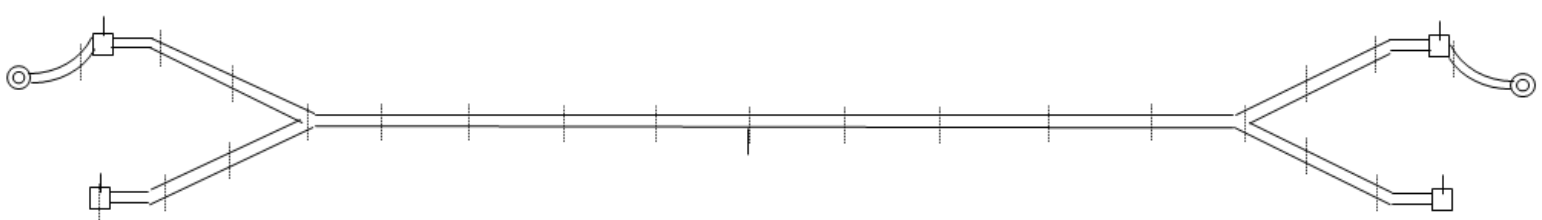

Rys. 3. Modelowanie przewodu głównego jednego wagonu 25 elementami MES

Fig. 3. Modelling of the main pipe of one wagon with 25 FEM elements

Przewód główny jest tzw. linią długą, przy przepływie przezeń powietrza zachodzą zjawiska falowe, następuje w nim wymiana ciepła między płynącym (w nim) powietrzem, a ściankami przewodu, a poszczególne odcinki wykazują zmienne opory przepływu. Procesy przepływowe i termodynamiczne zachodzące $\mathrm{w}$ przewodzie opisywane sa przez autora jednowymiarową metodą elementów skończonych (MES). Na rys. 3 przedstawiono przykładowe modelowanie przewodu głównego pojedynczego wagonu 25 elementami MES.

Przy analizach ogólnych hamowności pociąów wielowagonowych przewód główny modelować można minimalnie tylko jednym elementem skończonym na wagon, uzyskując mniejszą dokładność wyników, niż dla modelowania bardziej szczegółowego. W analizach dokładniejszych, na jeden wagon przyjmuje się przeważnie od kilku do kilkudziesięciu elementów skończonych o współczynnikach liczbowych utworzonych odrębnie dla każdego elementu, należą do nich:
The main pipe is so-called a long line. When the air flows through it the wave phenomena occur, there is the heat exchange between the flowing air (in it) and the walls of pipe, and the individual segments have the changeable flow resistance. The flow and thermodynamic processes occurring in the pipe are described by the author with the one-dimensional finite element method (FEM). Fig. 3 shows an example of modelling of the main pipe of a single wagon with 25 MES elements.

During analyses of the general braking of multiple wagons trains, the main pipe can be modelled with a minimum with only one finite element per a wagon obtaining the less accuracy of results than for a more detailed modelling. In the detailed analyses for one wagon from a few to several dozen of finite elements with numerical coefficients established separately for each element are mostly take. They include:

- length of the element

- resistance coefficient

- coefficient of walls thermal conductivity 
- długość elementu

- współczynnik oporu

- współczynnik przewodności cieplnej ścianek

-współczynnik objętości dodatkowych.

Sposób modelownia przepływów w przewodzie głównym determinuje dokładność uzyskanych wyników symulacji w porównaniu $\mathrm{z}$ procesem rzeczywistym. Zwłaszcza uwzględnienie w modelowaniu: zmian temperatury, współczynnika przewodności cieplnej ścianek i współczynnika objętości dodatkowych pozwala na uzyskanie dużej dokładności analiz. Uwzględnienie przewodności cieplnej zachodzącej między powietrzem w przewodzie, a ściankami przewodu pozwala na uzyskanie większej dokładności modelowania, gdyż szybkie rozchodzenia się fali hamowania jest procesem prawie adiabatycznym (nie zdąży zajść większa wymiana ciepła między powietrzem w przewodzie, a jego ściankami), a późniejszy powolny wzrostu siły hamowania jest procesem prawie izotermicznym.

W przypadkach występowania znacznych ślepych odgałęzień w objętości przewodu wpływają one bardzo niekorzystne na efektywność hamulca. Jeżeli odgałęzienia na przewodzie są dłuższe, niż jeden element skończony, to modeluje się je jako dodatkowe elementy MES, możliwe jest również umieszczanie na nich aparatów hamulcowych. Jeżeli odgałęzienia ( $\mathrm{z}$ ewentualnymi zmianami przekroju przelotu) są mniejsze, niż element MES, to uwzględnione to zostało przez autora przez wprowadzenie tzw. współczynnika objętości dodatkowych. Współczynnik ten uwzględnia niewielkie dodatkowe objętości występujące w rzeczywistym przewodzie poza objętością głównego przelotu przewodu głównego na tym odcinku . Sa to np. ślepe odgałęzienia, przyłącza różnych zaworów itd. Uwzględnienie tych objętości dodatkowych lub odgałęzień pozwala na znaczne zwiększenie dokładności analiz.

Walidację modelu przewodu głównego oparto na podstawie różnych wyników literaturowych pomiarów doświadczalnych (m.in. ORE, Knorr, CNTK, co rozpatrzono w [5]).

Dane modelu uściślono także w oparciu o wyniki własnych pomiarów doświadczalnych na stanowisku badawczym modelującym fragment przewodu głównego.

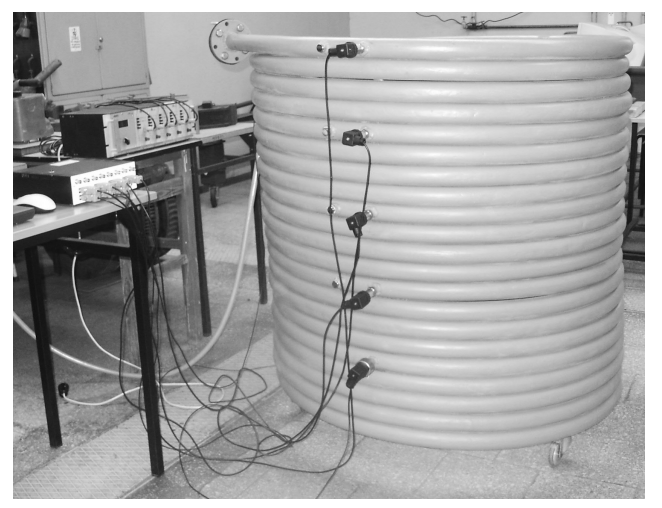

Rys. 5. Stanowisko badawcze odpowiadające fragmentowi przewodu głównego [5] Fig. 5. The research stand corresponding to the fragment of main pipe
- coefficient of additional volume.

The modelling way of flows in the main pipe determines the accuracy of the obtained simulation results in comparison with the real process. Especially taking into account in the modelling: temperature changes, coefficient of thermal conductivity coefficient of the walls and the coefficient of additional volume allows to obtain the high accuracy of analyses.

Taking into account the thermal conductivity occurring between the air in the pipe and the walls of the pipe allows to obtain the more accurate modelling, because the quick propagation of braking wave is nearly adiabatic process (the greater heat exchange between the air in the pipe and its wall does not manage to become) and the later slow growth of the braking force is almost isothermal process.

In the cases of occurring the large blind branches in the volume of pipe they very adverse impact on the effectiveness of the brake. If the branches on the pipe are longer than a finite element, they are modeled as MES additional elements, it is also possible to place on them the brake devices. If the branches (with the possible changes of the passage section) are less than the MES element, it is taken into account by the author by the introduction of so-called the coefficient of the additional volumes. This coefficient takes into account the small additional volumes occurring in the real of pipe apart from volume of the main passage of the main pipe in this section. There are for example: the blind branches, connections of different valves etc. Taking into account of these additional volumes or branches allows to increase significantly the accuracy of analyses.

Validation of the main pipe model is based on the different results of literature experimental measurements (inter alia ORE, Knorr, CNTK, which is considered in [5]).

The data of model are also specified experimental based on the results of own experimental measurements on the research stand modelling the fragment of the main pipe.

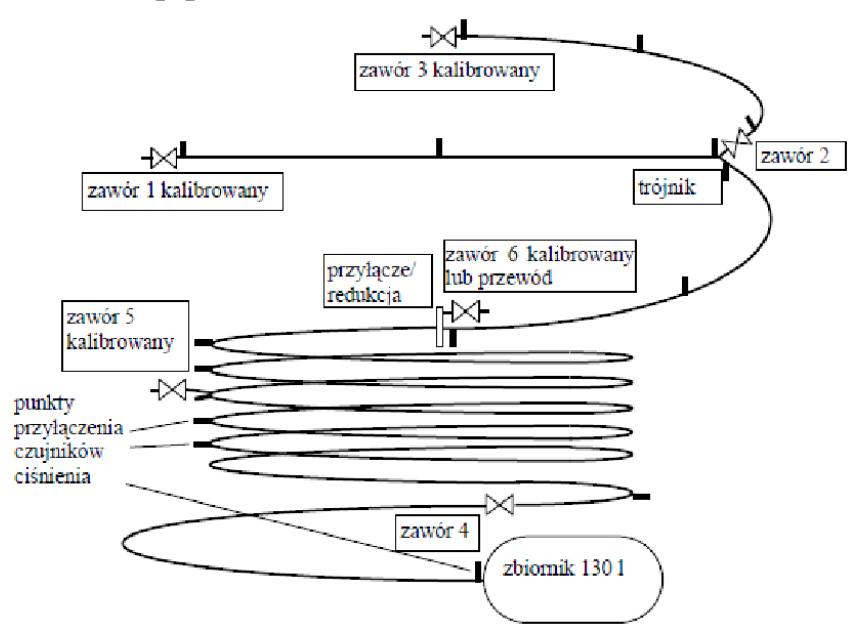

Rys. 4. Własne stanowisko badawcze z przewodem dł. $96 \mathrm{~m}$ [5] Fig. 4. Own research stand with the pipe with length of $96 \mathrm{~m}$ [5] 


\section{Urządzenia hamulcowe na poszczególnych po- jazdach}

\subsection{Zawory rozrządcze i pozostale urządzenia pneumatyczne}

Zawory rozrządcze, oraz komory i zbiorniki związane z nimi modelowane sa jako elementy dyskretne, czyli opisane równaniami różniczkowymi zwyczajnymi. W zależności od typu procesów $\mathrm{w}$ nich zachodzących opisuje się je różnymi typami przemian termodynamicznych. Najbardziej dokładne jest modelowanie uwzględniające wymianę ciepła przez ścianki zaworu. Elementy przepływowe modelowane są jako zawory lub jako dysze uogólnione (z przesunięciem punktu krytycznego względem modelu dyszy izentropowej), adiabatyczne lub $\mathrm{z}$ ewentualnym uwzględnieniem strat przepływu. Modele przepływów zaworów kolejowych zweryfikowane zostały doświadczeniami [7]. Otwieranie zaworów tłokami z membranami modelowane jest wariantowo jako:

- dwupozycyjne,

- proporcjonalne do siły, quasi statyczne,

- $\quad$ z uwzględnieniem dynamiki (i tarcia).

Wybór modelu zależy od typu procesu, celu modelowania i pożądanej dokładności wyników

Opracowano różne typy modeli zaworów rozrządczych, o różnej dokładności modelowania:

- zawór ogólny uproszczony (model średniej dokładności) umożliwiający uzyskanie dużej dokładności modelowania napełniania i opróżniania cylindrów w czasie hamowania, odhamowania i napełniania układu hamulca

- modele konkretnych zaworów o większej dokładności modelujące ich działanie również w sytuacjach nietypowych

- zawór Est3f

- zawór SW4 (wersja SW4-C S1-P-v)

- zawór ESH

- zawór KEd

- modele fragmentów zaworów rozrządczych, uwzględniające dynamikę ruchu elementów ruchomych [5].

$\mathrm{Z}$ modelem całopociagowym hamulca zintegrowano modele zaworów rozrządczych o średniej dokładności modelowania przyjmując przemiany izotermiczne. W modelu przepływów w dyszach i zaworach nie uwzględniono strat, a zawory są dwupozycyjne.

Wszystkie przedstawione zawory rozrządcze zostały przebadane na stanowisku badawczym i określono ich modele. Zdjęcia przedstawiają przykładowo zawór rozrządczy ESt3f na stanowisku badawczym. Należy zwrócić uwagę na dodatkowe punkty poboru ciśnienia z przestrzeni wewnątrz zaworu.

Do pozostałych urządzeń pneumatycznych zaliczono $\mathrm{w}$ modelu zawory bezpieczeństwa, nieszczelności (modelowane jako dysze), elektrozawory. Modelowane są one jako zawory adiabatyczne ze zmiennym w funkcji czasu otwarciem.

\section{Brake equipment on the individual vehicles 4.1. Control valves and other pneumatic equip- ment}

The control valves, the chambers and tanks connected with them are modeled as the discrete elements, which are described by ordinary differential equations. Depending on the type of processes taking place in them, they are described by the different types of thermodynamic processes. The most accurate it is modeling taking into account the heat exchange through the walls of the valve.

The flow elements are modeled as the valves or generalized adiabatic nozzles (with moving of the critical point to the model of the isentropic nozzle) or with the possible including the flow losses. The flow models of the railway waves are verified by the experiments [7]. Opening the valve with pistons with the membranes is modeled variantly as:

- two-position,

- proportionally to the force, quasi-static,

- taking into account the dynamics (and friction).

The choice of a model depends on the type of process, the aim of modelling and the desired accuracy of the results.

The different types of models of control valves, with different accuracy of modeling, are developed:

- general simplified valve (model with medium accuracy) allowing to obtain the high accuracy of modelling of filling and emptying the cylinders during braking, releasing and filling the brake system

- models of specific valves with the higher accuracy modeling their action also in unusual situations

- valve Est3f

- valve SW4 (version SW4-C S1-P-v)

- valve ESH

- valve KEd

- models of fragments of control valves, taking into account the dynamics of movement of moving elements [5].

The models of control valves with the medium accuracy of modelling are integrated with the model of the whole train brake assuming the isothermal processes. The losses are not included in the model flows in the nozzles and valves, and the valves are two-position.

All presented control valves are tested on the research stand and their models are defined. The pictures show as an example the ESt3f control valve on the research stand. It should be paid attention to the additional points of pressure intake from the space inside of the valve.

The safety valves, leakages (modeled as nozzles), the electrovalves are included to the other pneumatic equipment in the model. They are modeled as the adiabatic valves with the changeable opening in time function. 


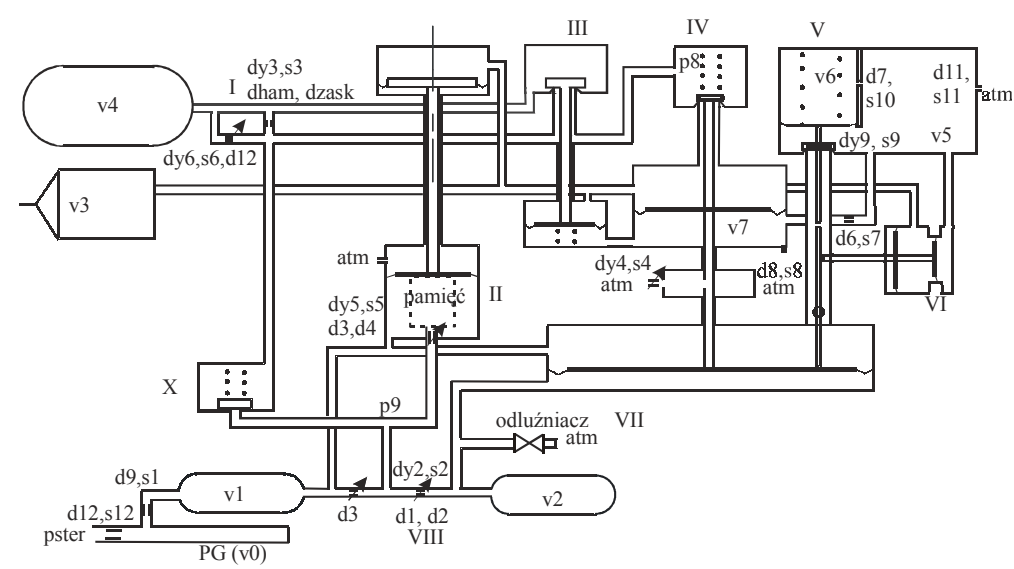

Rys. 6. Przykład wizualizacji modelu zaworu Est3f o średniej dokładności modelowania[5].

Fig. 6. Example of visualization of Est $3 \mathrm{f}$ valve model with the medium accuracy of modelling [5].

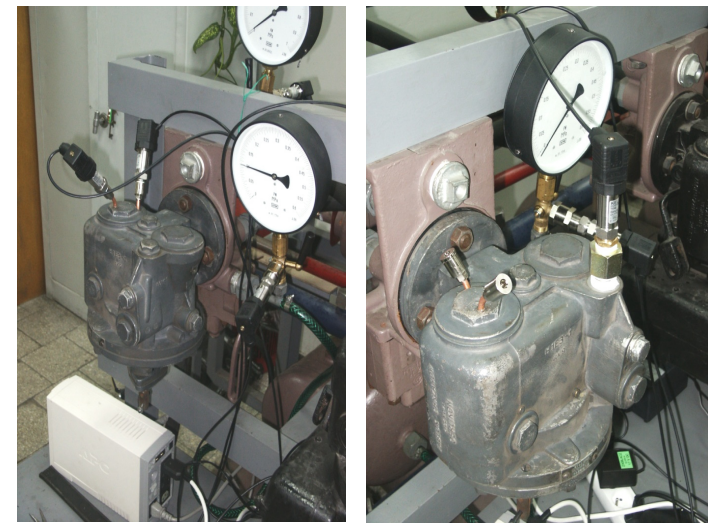

Rys. 7. Zawór rozrządczy ESt3f na stanowisku badawczym z dodatkowymi punktami poboru ciśnienia [5]

Fig. 7. ESt3f control valve on the research stand with the additional points of pressure intake [5]
Zawór rozrządczy zasila cylinder hamulcowy. Wytwarza on siłe mechaniczną docisku elementów ciernych hamulca. W przedstawionym $\mathrm{w}$ artykule, rozszerzonym modelu całopociagowym układu hamulcowego przyjęto możliwość wstawienia różnych par ciernych na poszczególnych wagonach, z współczynnikiem tarcia w postaci:

$$
\text { Współczynnik tarcia }=\left(w s p 1+\frac{w s p 2}{v+w s p 3}-w s\right.
$$

umożliwiający modelowanie różnorodnych par ciernych, co zaprezentowano przykładowo na rys. 8. Pominięto na rysunku wpływ zmiany nacisku par ciernych na współczynnik tarcia.

\section{Modelowanie dynamiki wzdłużnej}

Uwzględniono dwa typy modelowania:

- modelowanie pociagu sztywnego (bez uwzględnienia międzywagonowych elementów podatnych) - jest to wystarczające w analizach hamowności

- modelowanie pociaggu podatnego z uwzględnieniem elementów pociagowo-zderznych (czyli głównie zderzaków) i luzów międzywagonowych.

W wynikach symulacji zamieszczonych w niniejszym artykule wykorzystano modele zderzaka i amortyzatora urządzenia pociagowego o charakterystykach elementów elastomerowych.

\section{Przykłady wyników symulacji \\ 6.1. Przewód główny}

Przebieg ciśnień $\mathrm{w}$ trakcie hamowania nagłego pociągu 50-wagonowego przedstawiono na rys. 9. Nie przedstawiano zróżnicowanych wariantów przewodu głównego.

$\mathrm{W}$ artykule przedstawiono natomiast wyniki symulacji hamowania całego pociagu $\mathrm{w}$ większości dla różnych hamulców poszczególnych wagonów. Rozważania wpływu prędkości jazdy początku hamowania na przebieg sił wzdłużnych $\mathrm{w}$ pociagu przestawionow $[5]$.
The control valve supplies the brake cylinder. It produces the mechanical force of pressure of the brake friction elements. In the presented article, the possibility of placing the different friction pairs on the individual wagons in the extended model of braking system in the whole train are taken, with the friction coefficient in the form of:

\section{$w s p 4 \times v) \times(1-w s p 5 \times$ nacisk na klocek $)$}

allowing to model the various friction pairs, which is presented as an example in Fig. 8. The influence of a change of pressure of the friction pairs on the friction coefficient is omitted in the drawing.

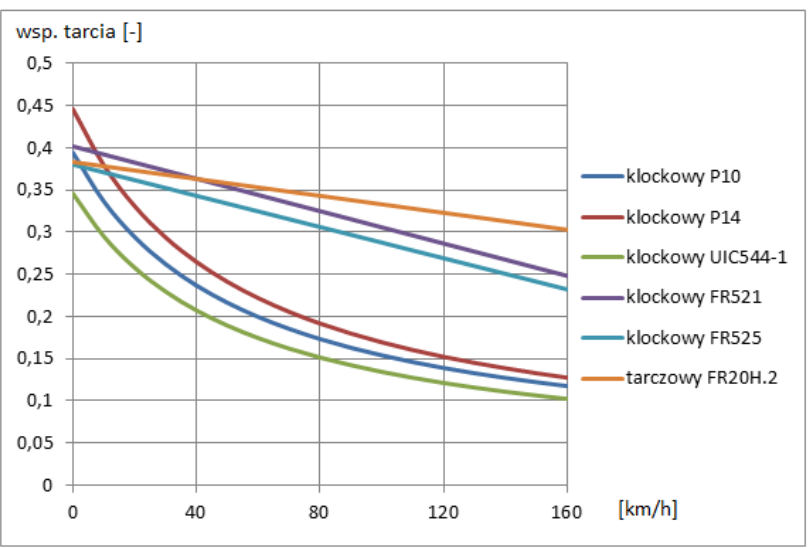

Rys. 8. Przykładowe charakterystyki współczynnika tarcia różnych materiałów ciernych i różnych typów hamulca [9].

Fig. 8. Exemplary friction coefficient characteristics of different friction materials and different types of brake [9].

\section{Modelling the longitudinal dynamics}

Two types of modelling are included:

- modeling of the rigid train (excluding the susceptible interwagon elements) - it is sufficient in the analyses of braking

- modelling of the susceptible train including the draw and buffer elements (i.e. mainly bumpers) and interwagon clearances. 


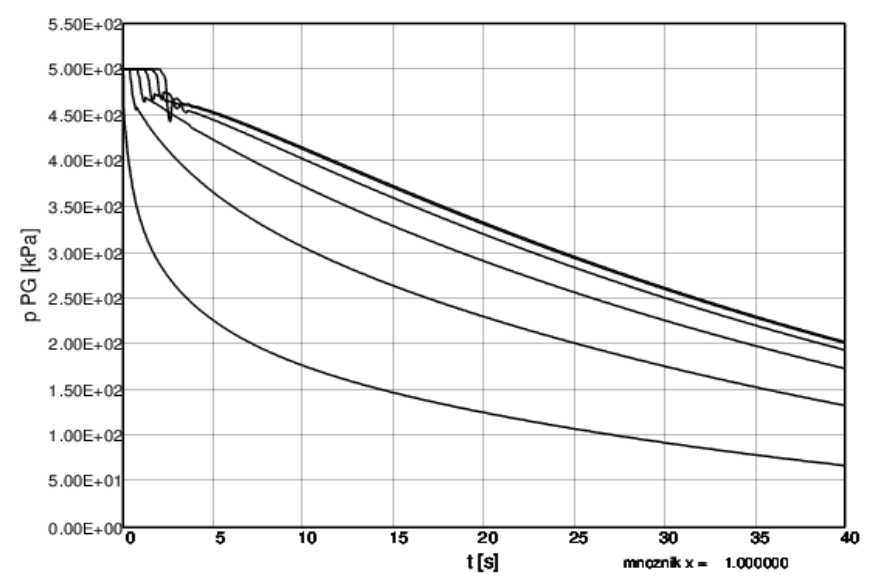

Rys. 9. Ciśnienia w przewodzie głównym, pociag towarowy 50. wagonowy, wagony 15 metrowe, wykresy dla 1-ego i co 10tego wagonu

Fig. 9. The pressure in the main pipe, the freight 50-wagon train, the wagon with length of 15 meters, charts for the 1st and every 10th wagon

\subsection{Hamulec klockowy, różne nastawy zaworów rozrządczych}

Czas napełniania cylindra hamulcowego pojedynczego wagonu wynosi $4 \mathrm{~s}$, w wagonach końcowych długiego pociagu następuje znaczne jego wydłużenie (rys. 10): różne nastawy zaworów rozrządczych wzdłuż pociągu, nastawienie „długa lokomotywa”: pierwsze 5 wagonów - nastawienie towarowy, pozostałe - osobowy.

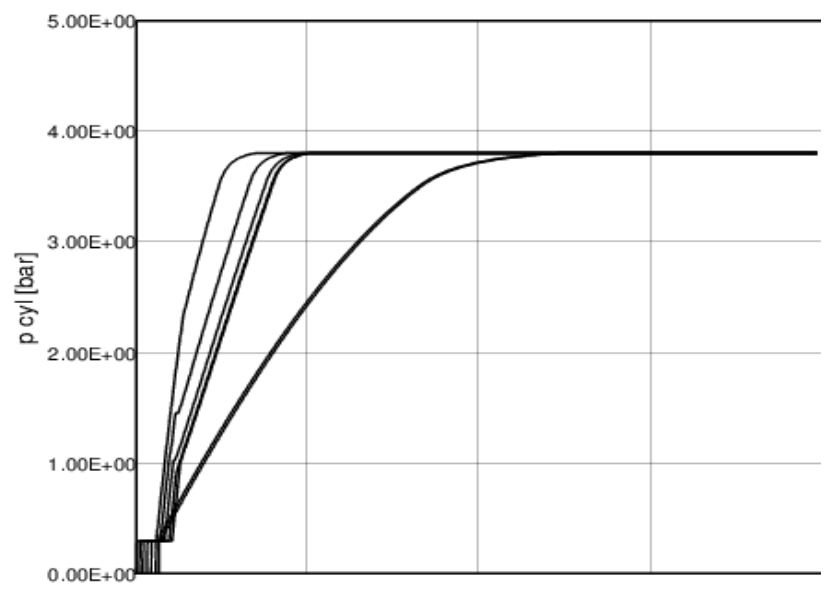

Rys. 11. Ciśnienia w cylindrach pociagu 30. wagonowego Fig. 11. The pressure in the cylinders of 30 - wagon train

Wprowadzone nastawienie „długa lokomotywa” różnicujące czas napełniania cylindrów wzdłuż pociagu powoduje mniejsze zróżnicowanie wzrostu ciśnień w cylindrach wagonów wzdłuż pociagu (rys. 11) przy tylko niewielkim wydłużeniu drogi hamowania pociągu i znaczne zmniejszenie wzdłużnych sił ściskających między wagonami składu (dla porównania rys. 12 i rys.13).
The models of bumper and shock absorber of the drawing device with characteristics of elastomeric elements are used in the simulation results given in this article.

\section{Examples of simulation results}

\subsection{Main pipe}

The course of pressure during emergency braking of 50 - wagon train is shown in Fig. 9. The different variants of the main pipe is not presented.

The article presents the results of the simulation during braking of the whole train mostly for the different brakes of the individual wagons. The considerations of the influence of riding speed of the braking beginning on the course of the longitudinal forces in the train are presented in [5].

\subsection{Shoe brake, various settings of control valves}

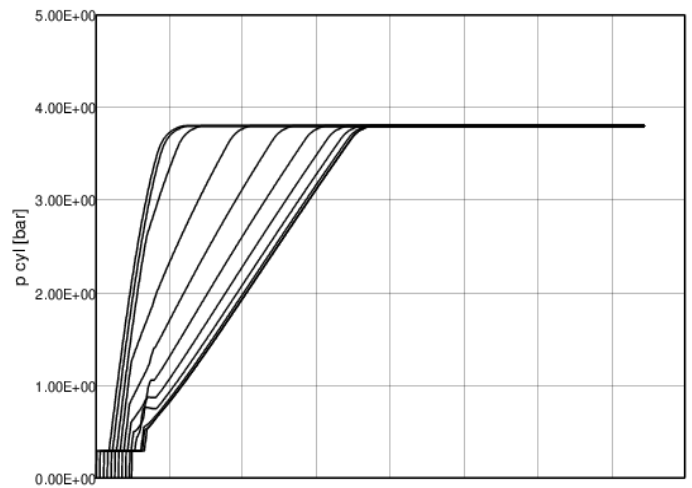

Rys. 10. Ciśnienia w cylindrach hamulcowych, pociag 50. wagonowy, $700 \mathrm{~m}$, wagony z czasem napełniania cylindra $4 \mathrm{~s}$

Fig. 10. The pressure in the brake cylinders, 50-wagon train, 700 $\mathrm{m}$, wagons with filling time of the cylinder $4 \mathrm{~s}$

Time of brake cylinder filling of a single wagon is $4 \mathrm{~s}$, in the end wagons of a long train it is much longer (Fig. 10): the various settings of control valves along the train, setting "long locomotive": the first 5 wagons- the setting freight, the others - passenger.

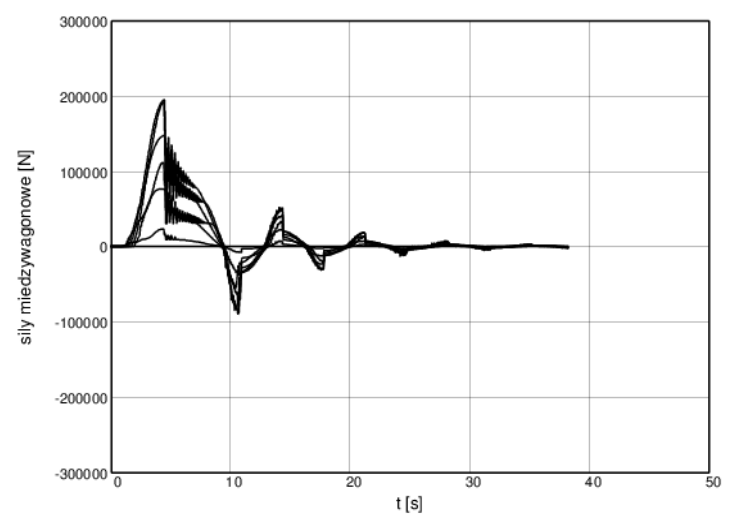

Rys. 12. Siły wzdłużne w pociągu, pociąg 30 . wagonowy, hamowanie z prędkości $100 \mathrm{~km} / \mathrm{h}$, hamulec klockowy, nastawienie "osobowy”

Fig. 12. Longitudinal forces in the train, 30- wagon train, braking from a speed of $100 \mathrm{~km} / \mathrm{h}$, the shoe brake, setting "passenger" 


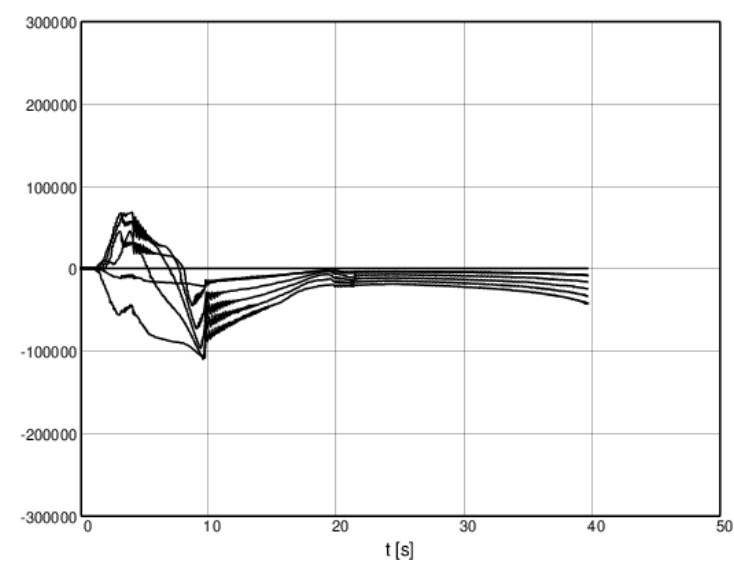

Rys. 13. Siły wzdłużne w pociągu, pociąg 30 . wagonowy, hamulec klockowy, hamowanie z prędkości $100 \mathrm{~km} / \mathrm{h}$, nastawienie ,długi pociag"

Fig. 13. Longitudinal forces in the train, 30 - wagon train, braking from a speed of $100 \mathrm{~km} / \mathrm{h}$, the shoe brake, setting "long train"

\subsection{Rodzaje par ciernych: hamulec klockowy lub tarczowy}

Rysunki 14 i 15 przedstawiają siły wzdłużne w pociągu $\mathrm{w}$ przypadku zastosowania hamulca tarczowego zamiast hamulca klockowego. Hamulec tarczowy w tym przypadku w dłuższym pociagu towarowym powoduje powstanie większych sił wzdłużnych.

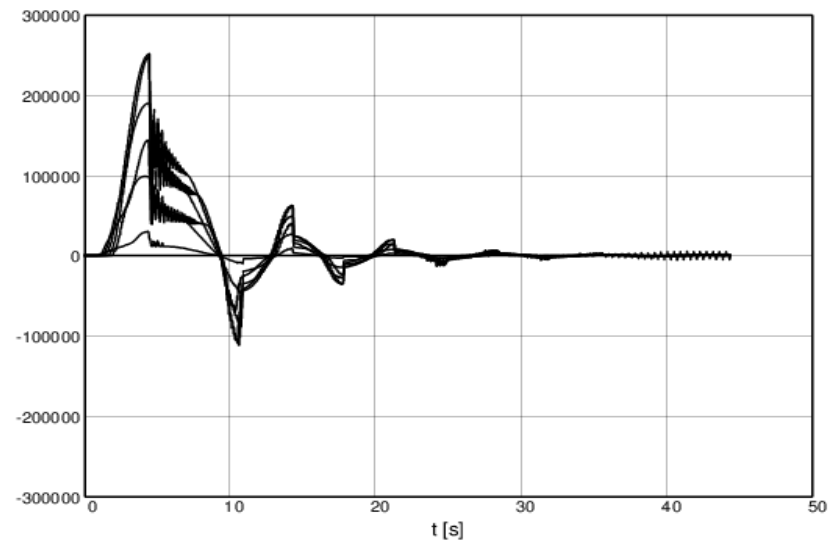

Rys. 15. Siły wzdłużne w pociagu 30 . wagonowym, hamowanie nagłe z $100 \mathrm{~km} / \mathrm{h}$, hamulec tarczowy, nastawienie „osobowy” Fig. 15. Longitudinal forces in the 30 - wagon train, emergency braking from a speed of $100 \mathrm{~km} / \mathrm{h}$, the disc brake, setting "passenger"

\subsection{Różne rodzaje par ciernych hamulca wzdłuż pociągu}

Poziom sił wzdłużnych w pociagu z mieszanymi elementami ciernymi (rys. 16 i 17) w porównaniu z jednolitymi elementami ciernymi (rys. 14 i 15) jest znacznie większy i w przypadku hamulców tarczowych w pierwszej części pociągu występujące pod koniec hamowania siły rozciągające mogą grozić zerwaniem składu.
The introduced setting "long locomotive" differentiating the time of filling of cylinders along the train causes the less variation of pressures growth in the cylinder of wagons along the train (Fig. 11) with only slight extension of the braking distance of the train and the significant reduction of longitudinal compressive forces between the wagons (for comparison Fig. 12 and Fig. 13).

\subsection{Types of friction pairs: shoe or disc brake}

Figures 14 and 15 show the longitudinal forces in the train in the case of using the disc brake instead of the shoe brake. The disc brake in this case in the longer freight train makes higher longitudinal forces occur.

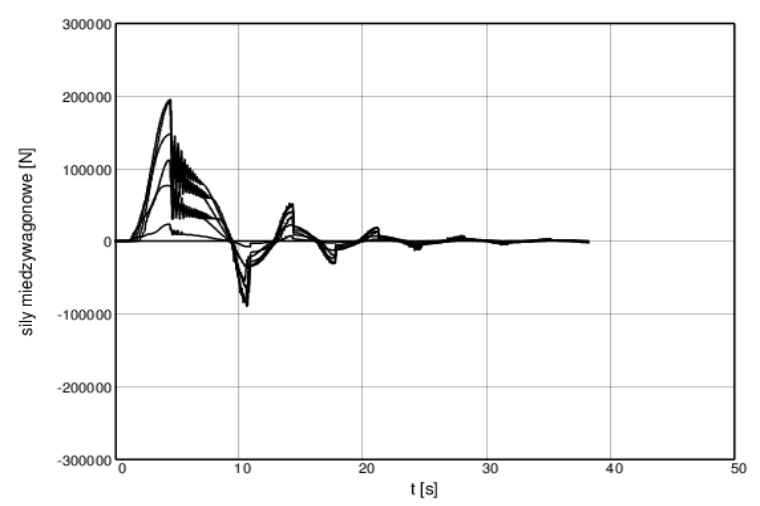

Rys. 14. Siły wzdłużne w pociągu, pociąg 30 . wagonowy, hamowanie z $100 \mathrm{~km} / \mathrm{h}$, hamulec klockowy, nastawienie „osobowy”

Fig. 14. Longitudinal forces in the train, 30 - wagon train, braking from a speed of $100 \mathrm{~km} / \mathrm{h}$, the shoe brake, setting "passenger"

\subsection{Different types of brake friction pairs along the train}

The level of the longitudinal forces in the train with the mixed friction elements (Fig. 16 and 17) in comparison with of uniformed friction elements (Fig. 14 and 15) is much bigger and in the case of disc brakes in the first part of train the occurring at the end of the braking tensile forces can threaten the train set to be broken.

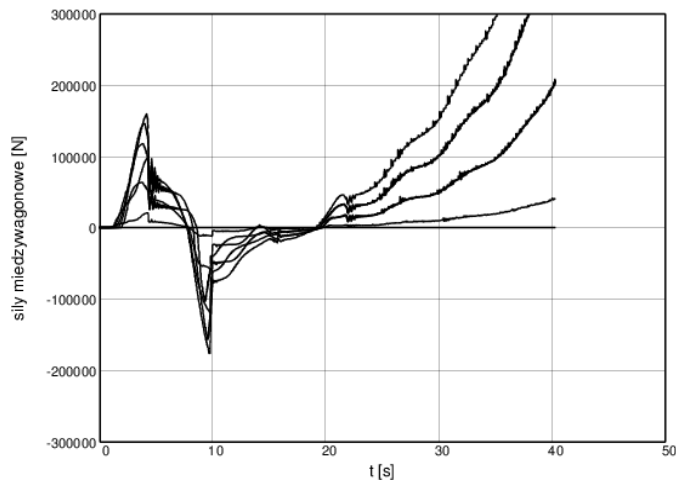

Rys. 16. Siły wzdłużne w pociagu 50. wagonowym, hamowanie nagłe z $100 \mathrm{~km} / \mathrm{h}$, różne rodzaje par ciernych wzdłuż pociagu $\mathrm{w}$ pierwszej połowie wagonów -hamulec klockowy, w tylnej tarczowy, nastawienie hamulca „osobowy”

Fig. 16. Longitudinal forces in the 50 - wagon train, emergency braking from $100 \mathrm{~km} / \mathrm{h}$, different types of friction pairs along the train in the first half of the wagons - shoe brake, in the rear - disc brake, brake setting "passenger" 


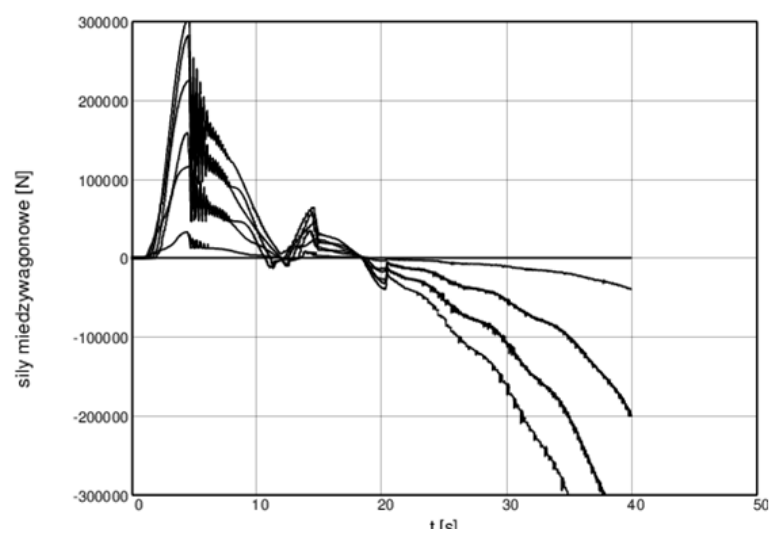

Rys. 17. Siły wzdłużne w pociagu 50. wagonowym, hamowanie nagłe z $100 \mathrm{~km} / \mathrm{h}$, przód pociagu - hamulec tarczowy, tył - hamulec klockowy, nastawienie ,osobowy” Fig. 17. Longitudinal forces in the 50 - wagon train, emergency braking from $100 \mathrm{~km} / \mathrm{h}$, the front of the train - disc brake, the rear - shoe brake, setting "passenger"

\section{Podsumowanie}

Przedstawiona modyfikacja metody pomimo, że dotyczy jedynie utworzenia w programie komputerowym rozszerzonej możliwości zmiennej konfiguracji modelu hamulca wzdłuż pociągu, ma duże znaczenie praktyczne. Pozwala wychwycić różnice w pracy całego układu hamulcowego przy istnieniu różnych typów hamulców na poszczególnych wagonach. Ma to istotne znacznie np. przy wprowadzaniu nowych elementów na części istniejących układów hamulcowych. Cel prezentowanego rozszerzenia opracowanej metody symulacji układu hamulcowego pociagu zaprezentowany w przykładowych symulacjach artykułu został zrealizowany. Metoda może być wykorzystana przy rozwiązywaniu zaawansowanych problemów hamowania niejednolitych pociagów $\mathrm{z}$ wykorzystaniem analiz symulacyjnych.

\section{Conclusions}

The presented modification of the method, despite the fact that it only concerns making in the computer program the extended possibility of the variable model configurations of the brake along the train, is important practically. It allows to identify the differences in the work of the whole brake system with the existence of different types of brakes on the individual wagons. This has the significant importance for example with introducing the new elements on the part of the existing braking systems. The purpose of the presented extension of the developed simulation method of the train braking system, presented in the exemplary simulations of the article, is realized. The method can be used to solve the advanced problems of braking of varied trains with using the simulation analyses.

\section{Literatura Bibliography}

1. Cantone L., Crescentini E.,RVerzicco R., Vullo V.: A numerical model for the analysis of unsteady train braking and releasing manoeuvres. Proc. IMechE Vol. 223 Part F: J. Rail and Rapid Transit. 2009.

2. Jianyong Z. Yuechao Lu: Simulation on Pneumatic Brake Control of train Based on Deceleration Feedback. 2011 Fourth International Conference on Intelligent Computation Technology and Automation.

3. Johansson R.: A fault-tolerant architecture for computer-based railway vehicle brake systems. Proc. Instn Mech. Engrs Vol. 218 Part F: J. Rail and Rapid Transit. 2004

4. Nankyo M., Ishihara T., Inooka H.: Feedback Control of Braking Deceleration on Railway Vehicle. Transactions of the ASME. Journal of Dynamic Systems, Measurement, and Control JUNE 2006, Vol. 128

5. Piechowiak T.: Badanie i modelowanie procesów zachodzacych w układach pneumatycznych pociagów. Politechnika Poznańska, Rozprawy Nr 414, 2007, s. 155

6. Piechowiak T.: Pneumatic train brake simulation method. Vehicle System Dynamics. Vol. 47, Issue 12, December 2009, s. 1473-1492.

7. Piechowiak T.: Verification of the pneumatic railway brake models. Vehicle System Dynamics, Vol. 48, Issue 3, March 2010 , s. 283-299.

8. Piechowiak T.: Hamulce pojazdów szynowych. Wydawnictwo Polit. Poznańskiej, 2012 r., s. 321.

9. Praca zespolowa pod kier. T. Piechowiaka. Raport w/s możliwości uzyskania minimum 151\% masy hamujacej przy wzroście masy własnej wagonu. Stowarzyszenie Inżynierów i Techników Komunikacji Rzeczpospolitej Polskiej. Oddziat w Poznaniu 2014. Praca niepublikowana.

10. Pugi I., Malvezzi M., Allotta B., Banchi L., Presciani P.: A parametric library for the simulation of a Union Internationale des Chemins de Fer (UIC) pneumatic braking system. Proc. Instn Mech. Engrs Vol. 218 Part F: J. Rail and Rapid Transit. 2004

11. Specchia S., Afshari A., Shabana A., Caldwell N.: A train air brake force model: Locomotive automatic brake valve and brake pipe flow formulations. Proceedings of the Institution of Mechanical Engineers, Part F: Journal of Rail and Rapid Transit 2013, 227. 